\title{
Antibiotic Resistance Pattern Among Gram Negative Mercury Resistant Bacteria Isolated From Contaminated Environments
}

\author{
Nima Mirzaei ${ }^{1, *}$, Hilda Rastegari ${ }^{2}$, Mehdi Kargar ${ }^{2}$ \\ ${ }^{1}$ Department of Microbiology, Science and Research Branch, Islamic Azad University, Tehran, IR Iran \\ ${ }^{2}$ Department of Microbiology, Jahrom Branch, Islamic Azad University, Jahrom, IR Iran \\ ${ }^{*}$ Corresponding author: Nima Mirzaei, Department of Microbiology, Science and Research Branch, Islamic Azad University, Tehran, IR Iran. Tel: +98-2188984446, Fax: +98-2188957409, \\ E-mail:nm_mirzaei@yahoo.com.
}

Received: September 6, 2012; Revised: February 3, 2013; Accepted: February 18, 2013

\begin{abstract}
Background: Mercury is one of the most toxic heavy metals. Even a small amount of it is toxic for all living organisms. Some of bacteria have developed special resistance mechanisms against mercury, in addition to resistant to different antibiotics. These bacteria usually acquire $\mathrm{Hg}$ and antibiotic resistance genes via horizontal gene transfer in their habitat.

Objectives: The aim of this study was isolation and identification of mercury resistant bacteria and evaluating the relation between increase of environmental levels of mercury and prevalence of antibiotic resistance among Gram negative $\mathrm{Hg}$ resistant bacteria.

Materials and Methods: The samples were collected from water and sediments of Kor River. We evaluated amounts of mercury in the water and sediment samples and counted the number of bacteria in both $\mathrm{Hg}$ containing and non-Hg containing media. Antibiotic resistance pattern was studied using disk diffusion method for $\mathrm{Hg}$ resistant and $\mathrm{Hg}$ sensitive bacteria.

Results: The frequencies of mercury resistant bacteria were between $35 \%$ for Pole Khan station and $2.5 \%$ for Doroodzan station. These stations were the most and the lowest mercury-contaminated areas of the Kor River respectively. Pseudomonas sp., Entrobacter sp., Escherichia coli, Klebsiella sp. And Serratia marcescens were isolated as mercury resistant bacteria. The highest level of antibiotic resistance was seen for ampicillin, tetracycline and sterptomycin. Antibiotic resistance frequencies among these bacteria were higher than mercury sensitive ones.

Conclusions: Our results showed that $\mathrm{Hg}$ resistance genes in contaminated areas are exchanged between residing bacteria along with the antibiotic resistance genes and resulted in prevalence of antibiotic resistance among residing bacteria.
\end{abstract}

Keywords: Multiple Antibiotic Resistance; Mercury; Tetracycline

\section{Background}

Nowadays public health authorities are concerned about toxic chemicals such as mercury which is found in the rivers and enters the human body through sea foods consumption (1). Naturally, mercury exists in the environment in small amounts; however its level has increased due to human activities (2). Mercury enters and aggregates in tissues, binds to the sulfhydryl groups of the enzymes and causes serious problems in humans (3). Consumption of methylmercury, the most toxic form of mercury, may cause Minamata disease which is distinguishable by different neurological symptoms in human (4). Even small amounts of mercury are toxic for all living organisms; however some bacteria residing in contaminated areas can exchange resistance genes due to continual exposure to the toxic levels of mercury and become resistant to it (3).
Resistance to mercury is controlled by a set of genes organized in an operon named mer. mer operon consists of mer RTPABD genes. Regulation of gene expression in mer operon is controlled by merD and merR. merP and merT are involved in transporting $\mathrm{Hg}$ into the cytoplasm, merB degrades organic mercury and finally merA encodes Mercuric reductase. This enzyme reduces $\mathrm{Hg}^{2+}$, one of the most toxic forms of mercury, to metallic mercury $\mathrm{Hg}^{0}$ which is less toxic and not stable in the environment. So it plays the key role in mercury bioremediation process (5-7). Barkay et al. first reported bacterial resistance to mercury compounds in a clinically isolated Staphylococcus aureus (8).

Ray et al. evaluated the ability of $\mathrm{N}_{2}$ fixing bacteria (Beijerinckia and Azotobacter) to remove mercury. They reported that there is a direct relationship between increased use of herbicides and spreading resistant to mercury in

Implication for health policy/practice/research/medical education:

The increase of environmental mercury pollution not only affects all living organisms but also results in spreading multiple antibiotic resistance among residing bacteria especially in Gram negative bacteria. This will be a serious public health problem in contaminated regions.

Copyright (C) 2013, Ahvaz JundishapurUniversity of Medical Sciences; Published by Kowsar Corp. This is an open-access article distributed under the terms of the Creative Commons Attribution License, which permits unrestricted use, distribution, and reproduction in any medium, provided the original work is properly cited. 
bacterial communities residing in agricultural soils (9). Enhancement of mercury contamination increases antibiotic resistant strains. This is a serious environmental and public health concern in such regions (10-12). Moreover, using mercury-containing products such as disinfectants and amalgam may cause spreading of multiple antibiotic resistance strains in hospitals and human intestine $(3,13)$.

Most of mercury resistance genes are located adjacent to antibiotic resistance genes. These genes are found in mobile plasmids and transposons which can be exchanged between bacterial strains and species (14-16). Kor River is the main river in Fars province and supplies the drinking water of Shiraz (the largest city in the south west of Iran). The factories wastewater such as Petroshimi chloralkali unit which contains high amounts of mercury is discharged into Kor River. High levels of mercury have been accumulated throughout the river for many years.

\section{Objectives}

The main objective of this work was to isolate and identify mercury resistant bacteria in the water and sediments of Kor River and determine whether increasing amounts of $\mathrm{Hg}$ in the environment could spread multiple antibiotic resistance among bacterial communities residing in these areas.

\section{Materials and Methods}

\subsection{Study Area}

Considering industrial and agricultural activities along the Kor River bank, the study area stretched from Doroodzan dam to Bakhtegan Lake, which comprised of four stations. The position and coordination of the sampling stations was determined by GPS (Global Positioning System) (Table 1).

Table 1. Position of the Sampling Sites

\begin{tabular}{lllll}
\hline Sampling Sites & Altitude, $\mathbf{m}$ & Description & \multicolumn{2}{c}{ Coordinates } \\
\cline { 4 - 6 } & & & Longitude & Latitude \\
\hline Droodzan (D) & 1634 & after Droodzan barrier, without any wastewater & $52^{\circ} 25^{\circ} 32^{\prime \prime} \mathrm{E}$ & $30^{\circ} 12^{\circ} 22^{\prime \prime} \mathrm{N}$ \\
Pole Petroshimi (PP) & 1593 & after wastewater output of a chlor-alkali plant & $52^{\circ} 45^{\circ} 39^{\prime \prime} \mathrm{E}$ & $29^{\circ} 51^{\circ} 42^{\prime \prime} \mathrm{N}$ \\
\hline Pole Khan (PKh) & 1588 & after Sivand river entrance, containing urban wastewater & $52^{\circ} 46^{\circ} 15^{\prime \prime} \mathrm{E}$ & $29^{\circ} 50^{\circ} 89^{\prime \prime} \mathrm{N}$ \\
\hline Ghavmishi $(\mathbf{G})$ & 1563 sites & ending of Kor river, near lake Bakhtegan & $52^{\circ} 25^{\circ} 00^{\prime \prime} \mathrm{E}$ & $29^{\circ} 32^{\prime} 51^{\prime \prime} \mathrm{N}$ \\
\hline
\end{tabular}

\subsection{Sampling}

The samples were collected from surface water as well as sediments in four stations throughout the river. Sampling was performed three times during three weeks. For microbial studies, the samples were collected in sterile glass containers. For measuring the amounts of mercury, the samples were collected in nitric acid pre-rinsed polyethylene containers. Electrical conductivity (EC), $\mathrm{pH}$ and temperature of the water samples were determined at the sampling sites (Table 2). The samples were then placed into cooler boxes and transferred to the laboratory ( 17 ).

\begin{tabular}{llll}
\hline Table 2. Features of the Water Samples & & \\
\hline Sampling Sites & pH & EC & Tm \\
\hline Droodzan & 6.9 & 489 & 16 \\
Pole Petroshimi & 8.2 & 1124 & 18 \\
Pole Khan & 8.4 & 1133 & 17 \\
Ghavmishi & 8.1 & 1062 & 19 \\
\hline
\end{tabular}

\subsection{Sample Preparation}

Samples were prepared before measuring the amounts of mercury. Water samples were first filtered using $42 \mu \mathrm{m}$ Whatman filter paper. The filtered samples were digested with a mixture of $3 \mathrm{~mL}$ of nitric acid and $1 \mathrm{ml}$ of chloridric acid. Sediment samples were dehydrated using an oven at $103^{\circ} \mathrm{C}$ for 2 hours and pulverized to uniform particle sizes. The pulverized samples were digested with a mixture of $6 \mathrm{ml}$ of nitric acid and $2 \mathrm{~mL}$ of perchloric acid for every $1 \mathrm{~g}$ of samples and heated. Finally, digested samples were filtered using $42 \mu \mathrm{m}$ Whatman filter paper (17).

\subsection{Mercury Analysis}

Following the preparation, all samples were analyzed for the presence of $\mathrm{Hg}$ by cold vapor atomic absorption spectrophotometery using inductive coupled plasma (ICP) Varian model.

\subsection{Bacterial Enumeration}

After transferring the samples to the laboratory, enu- 
meration of bacteria was performed using total viable plate count. All samples were serially diluted in phosphate buffered saline (PBS) (2.2 $\mathrm{g}$ of $\mathrm{NaH}_{2} \mathrm{PO}_{4}$ per liter, 6 $\mathrm{g}$ of $\mathrm{Na}_{2} \mathrm{HPO}_{4}$ per liter, $5.8 \mathrm{~g}$ of $\mathrm{NaCl}$ per liter $[\mathrm{pH}=7.2]$ ). Serial dilutions from 10-1 to 10-10 were prepared. From each dilution, $0.1 \mathrm{~mL}$ was speared on Luria-Bertani agar (LB agar) (Merck, Germany) (10 g of peptone per liter, $5 \mathrm{~g}$ of yeast extract per liter, $10 \mathrm{~g}$ of $\mathrm{NaCl}$ per liter, $12 \mathrm{~g}$ of agar per liter). The plates were incubated at $30^{\circ} \mathrm{C}$ for 48 hours. After the incubation period, the appeared colonies were enumerated (18).

\subsection{Isolation and Identification of Mercury Resistant Bacteria}

Isolation of mercury resistant bacteria was performed according to the method described in our previous study (19). One $\mathrm{g}$ of each sample was added to $9 \mathrm{~mL}$ of $\mathrm{LB}$ broth medium (10 g of peptone per liter, $10 \mathrm{gr} \mathrm{NaCl}$ per liter) containing $10 \mathrm{mg}$ of $\mathrm{HgCl}_{2}$ per liter and incubated at $30^{\circ} \mathrm{C}$ for 48 hours. After the incubation period, $0.1 \mathrm{~mL}$ of enrichment culture was speared on LB agar and incubated at $30^{\circ} \mathrm{C}$ for 48 hours. The appeared colonies were purified and identified using Gram staining and conventional biochemical tests according to the method of Bergey (20).

\subsection{Antibiotic Resistance}

Antibiotic resistance susceptibility was assessed using disk diffusion method according to NCCLS instructions
(21). A single colony was picked and added to containing $\mathrm{HgCl}_{2}$ and without $\mathrm{HgCl}_{2} \mathrm{LB}$ broth media and incubated at $37^{\circ} \mathrm{C}$ for 24 hours. The turbidity of media were compared to the 0.5 McFarland standard, then spread on Muller Hinton agar using sterile swabs. Finally, antibiotic discs (MAST, England) were located on the surface of the plates. The following antibiotic discs were used in this study: Ampicillin (AM) $10 \mu \mathrm{g}$, Streptomycin (S) $10 \mu \mathrm{g}$, Gentamycin (GM) $10 \mu \mathrm{g}$, Nalidixic Acid (NA) $30 \mu \mathrm{g}$, Tetracycline (TE) $30 \mu \mathrm{g}$ and Chloramphenicol(C) $30 \mu \mathrm{g}$.

\subsection{Data Analysis}

Data analysis was performed by ANOVA and Duncan tests. All statistical analyses were done using SPSS software Version 12 with significance based on $0.05(\mathrm{P}<0.05)$ in most of the cases.

\section{Results}

\subsection{Amount of Mercury}

The highest levels of mercury were 0.083 and 0.769 ppm. These amounts were achieved from Pole khan Station water and sediments samples, respectively. The lowest amounts of mercury (0.011 and $0.248 \mathrm{ppm}$ ) were obtained from the water and sediment samples of Doroodzan Station. There was a significant difference $(\mathrm{P}<$ $0.05)$ between amounts of mercury in different stations (Table 3).

Table 3. Amounts of $\mathrm{Hg}$ in the Samples

\begin{tabular}{lllll}
\hline \multirow{2}{*}{ Type of Samples } & \multicolumn{4}{c}{ Sampling Sites } \\
\cline { 2 - 5 } & Droodzan & Pole Petroshimi & Pole Khan & Ghavmishi \\
\hline Sediment, ppm & $0.248 \pm 0.179$ & $0.671 \pm 0.048$ & $0.769 \pm 0.038$ & $0.634 \pm 0.053$ \\
Water, ppm & $0.011 \pm 0.043$ & $0.093 \pm 0.035$ & $0.083 \pm 0.005$ & $0.077 \pm 0.005$ \\
\hline
\end{tabular}

\subsection{Bacterial Enumeration}

Average number of mercury resistant bacteria and total bacteria were $5.9 \times 10^{6}$ and $2 \times 10^{7} \mathrm{CFU} / \mathrm{mL}$ respectively. There is a significant difference $(\mathrm{P}<0.05)$ between the average number of mercury resistant bacteria and total bacteria. A comparison between the stations was performed in terms of the number of mercury resistant bacteria. The two highest numbers of mercury resistant bacteria, $8.2 \times 10^{6}$ and $1.4 \times 10^{7} \mathrm{CFU} / \mathrm{mL}$ were obtained from Pole petroshimi and Pole khan, respectively. The lowest number was $1.4 \times 10^{5} \mathrm{CFU} / \mathrm{ml}$ for Doroodzan station. There is a significant difference $(\mathrm{P}<0.05)$ between the average number of mercury resistant bacteria isolated from different stations (Table 4, Figure 1).

Table 4. Frequencies of Mercury Resistant Bacteria

\begin{tabular}{llll}
\hline Sampling Sites & Total Bacteria, CFU/mL & Hg Resistant Bacteria, CFU/mL & Hg Resistant Bacteria, \% \\
\hline Droodzan (D) & $5.6 \times 10^{6}$ & $1.4 \times 10^{5}$ & 2.5 \\
Pole Petroshimi (PP) & $3.1 \times 10^{7}$ & $8.2 \times 10^{6}$ & 26 \\
Pole Khan (PKh) & $3.7 \times 10^{7}$ & $1.4 \times 10^{7}$ & 35 \\
Ghavmishi (G) & $8.6 \times 10^{6}$ & $1.5 \times 10^{6}$ & 20 \\
\hline
\end{tabular}




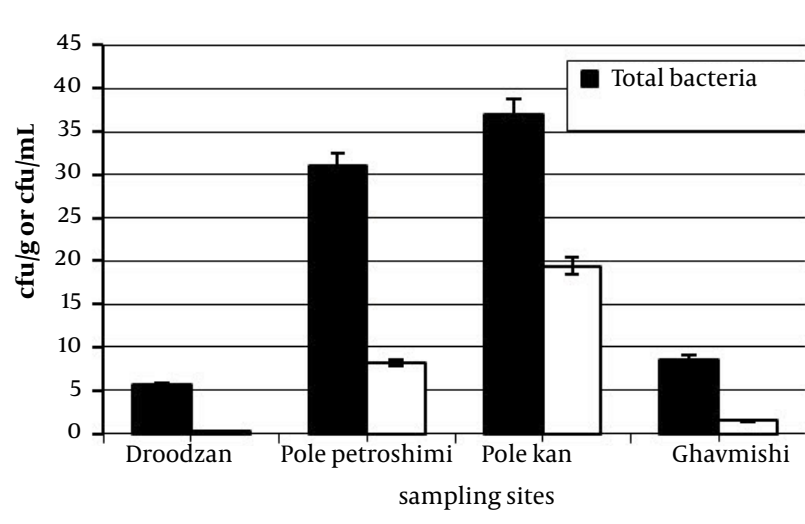

Figure 1. Distribution of the Total and Mercury Resistant Bacteria in the Sampling Sites

\subsection{Isolation and Identification of Mercury Resistant Bacteria}

Mercury resistant isolates from different stations are shown in Table 5 . The most common isolated bacteria were Serratia marcescens (83.3\%) and the least common ones were Acinetobacter (25\%) (Table 5).

\subsection{Antibiotic Resistance}

Of 55 mercury resistant strains, the highest frequencies of antibiotic resistance were obtained for ampicillin (62\%), tetracycline (53\%), and streptomycin (42\%) (Table $6)$. A higher frequency of antibiotic resistance was seen among mercury resistant strains in comparison to the sensitive strains. Many of $\mathrm{Hg}$ sensitive strains were also sensitive to all of the antibiotics.

Table 5. Mercury Resistant Species Isolated From Different Sampling Sites

\begin{tabular}{|c|c|c|c|c|c|c|c|c|c|c|c|c|c|}
\hline \multirow[b]{3}{*}{ Isolated bacteria, No. } & \multicolumn{12}{|c|}{ Sampling Sites } & \multirow{3}{*}{$\begin{array}{l}\text { Percentage } \\
\text { of Resistant } \\
\text { Strains }\end{array}$} \\
\hline & \multicolumn{3}{|c|}{ Droodzan } & \multicolumn{3}{|c|}{ Pole Petroshim } & \multicolumn{3}{|c|}{ Pole Khan } & \multicolumn{3}{|c|}{ Gavmishi } & \\
\hline & 1 & 2 & 3 & 1 & 2 & 3 & 1 & 2 & 3 & 1 & 2 & 3 & \\
\hline Klebsiella sp. & - & - & + & - & + & + & + & + & + & - & + & - & 58.3 \\
\hline E.coli & + & + & - & + & + & + & - & + & + & + & - & - & 66.7 \\
\hline Serratia marcescens & + & + & + & - & + & + & + & + & + & - & + & + & 83.3 \\
\hline Proteussp. & - & - & - & + & + & + & + & + & - & + & - & - & 50 \\
\hline Citrobacter sp. & - & - & - & + & - & - & + & - & - & + & + & + & 41.6 \\
\hline Pseudomonas sp. & + & + & + & - & - & + & + & + & - & + & + & + & 75 \\
\hline Acinetobacter sp. & - & - & - & + & - & + & + & - & - & - & - & - & 25 \\
\hline Enterobacter sp. & + & + & + & + & - & + & - & - & + & + & - & - & 58.3 \\
\hline
\end{tabular}

Frequencies of antibiotic resistance were between $8 \%$ to $24 \%$ for $\mathrm{Hg}$ sensitive and $22 \%$ to $62 \%$ for $\mathrm{Hg}$ resistant strains (Figure 2). Statistical analysis showed a significant difference between these data $(\mathrm{P}<0.05)$. Moreover, the most antibiotic resistant strains were isolated from Pole khan station.

Resistance to at least two antibiotics was seen in most of $\mathrm{Hg}$ resistant strains, but none of them were resistant to all six tested antibiotics. 40 strains (73\%) showed resistance to at least two antibiotics; tetracycline + chloramphenicol, tetracycline + Streptomycin or ampicillin + tetracycline (Table 7).
Table 6. Distribution of Antibiotic Resistance Frequencies

\begin{tabular}{lll}
\hline $\begin{array}{l}\text { Antibiotics Concen- } \\
\text { tration, } \boldsymbol{\mu g}\end{array}$ & $\begin{array}{l}\text { Number of Re- } \\
\text { sistant Strains }\end{array}$ & $\begin{array}{l}\text { Percentage of } \\
\text { Resistant Strains }\end{array}$ \\
\hline Ampicillin, 10 & 34 & $62 \%$ \\
\hline Nalidixic acid, 30 & 12 & $22 \%$ \\
\hline Steptomycin, 10 & 23 & $42 \%$ \\
\hline Gentamicin, 10 & 14 & $25 \%$ \\
\hline $\begin{array}{l}\text { Tetracycline, 30 } \\
\text { Chloramphenicol, } \\
\text { 30 }\end{array}$ & 29 & $53 \%$ \\
\hline
\end{tabular}

Table 7. Distribution of Multiple Antibiotic Resistant Strains

\begin{tabular}{ll}
\hline Antibiotics & Resistant Strains, No. (\%) \\
\hline Ampicillin + Streptomycin + Gentamicin + Nalidixixc acid & $1(2 \%)$ \\
Tetracycline + Chloramphenicol & $8(15 \%)$ \\
Tetracycline + Steptomycin & $17(31 \%)$ \\
Tetracycline + Ampicillin & $14(25 \%)$ \\
Total & $40(73 \%)$ \\
\hline
\end{tabular}




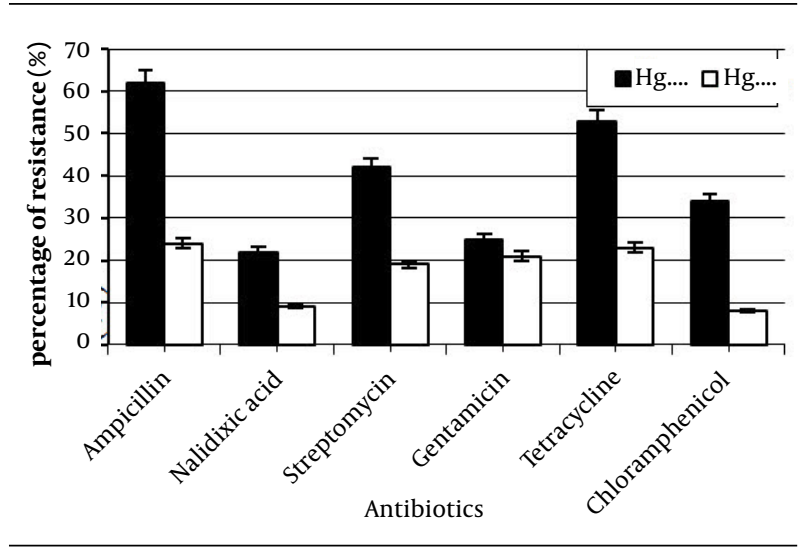

Figure 2. Antibiotic Resistance Levels Among Hg Resistant and Sensitive Bacteria

\section{Discussion}

Previous studies also reported Pole khan and Pole Petroshimi as the most mercury-contaminated areas of the Kor River (22). Pole Petroshimi is placed in the vicinity of a Chloralkali plant. Marvdasht urban wastewater, Azmayesh industries, Shiraz and Abbarik industrial town wastewaters are discharged directly into the Kor River near the Pole khan station. There are no industrial activities in the Doroodzan region; hence the highest and lowest contamination levels were obtained for Pole petroshimi and Doroodzan stations, respectively. To increase the chance of detecting mercury resistant bacteria, we used higher concentrations of $\mathrm{Hg}(10 \mathrm{mg} / \mathrm{mL})$ in growth media as described previously $(23,24)$.

Jaysankar et al. and Aram et al. found that the number of bacteria in mercury-containing media is lower in comparison with the media without $\operatorname{Hg}(25,26)$. In this study, the frequency of mercury resistant bacteria was also lower than those in the control medium. Presence of $\mathrm{Hg}$ in the medium may inhibit the bacterial growth. Mercury easily penetrates into the bacterial cell and interacts with the sulfhydryl groups of some amino acids such as cysteine. Hg covalently bonds to sulfur in the sulfhydryl groups and inactivates many proteins and enzymes by formation of the inhibiting disulfide bridges between the two cysteines (27).

In the present study, the highest frequencies of $\mathrm{Hg}$ resistant bacteria were $35 \%$ and $26 \%$ for Pole Khan and Pole Petroshimi stations, respectively, which were the most contaminated areas. Our results confirmed that there is a direct relationship between the number of isolated mercury resistant bacteria and the levels of environmental mercury. In mercury contaminated areas, bacteria can exchange plasmids and transposons carrying mercury resistance genes. This event increases the number of resistant bacteria in such environments (28).

Resistance to mercury has been reported in a wide range of bacterial genus particularly in Gram negative bacteria. In some earlier studies, Pseudomonas, Alcaligenes, E. coli and Klebsiella were identified as Gram negative $\mathrm{Hg}$ resistant genus (29-31). Petrova et al. also detected Pseudomonas, Acinetobacter and Plesiomonas as Gram negative $\mathrm{Hg}$ resistant bacteria (32). Similar results were also obtained in this study. Such resistant bacteria in extreme environmental conditions can exchange $\mathrm{Hg}$ resistant genes trough conjugation or transposition. The first step of interaction between bacterium and $\mathrm{Hg}$ in the environment is passing $\mathrm{Hg}^{2+}$ through the bacterial cell wall. Presence of outer membrane in Gram negative bacteria can inhibit the entrance of toxic chemicals into the cytoplasm; hence Gram negative bacteria are less affected in comparison to Gram positive ones. This natural barrier clearly increases the probability of isolation of Gram negatives bacteria from mercury contaminated environments.

$\mathrm{Hg}$ resistance genes are inducible. They are usually located on plasmids and transposons such as NR1, Tn21, Tn4, Tn2571, Tn1696, etc. which carry antibiotic resistance genes as well. These mobile elements encode resistance to different antibiotics such as streptomycin, ampicillin, chloramphenicol and tetracycline. These antibiotics have been frequently used in the previous studies for evaluating drug resistance prevalence among mercury resistant bacteria $(30,33,34)$. We chose these antibiotics to test any possible connection between $\mathrm{Hg}$ contamination and multiple antibiotic resistance among the isolates. In this study, antibiotic resistance frequencies were higher among $\mathrm{Hg}$ resistant bacteria in comparison with the sensitive bacteria. The antibiotic resistance frequencies were similar to the result obtained in previous studies. Antibiotic resistance frequencies for ampicillin, tetracycline, streptomycin and chloramphenicol were between 30\% to $60 \%$ which were similar to the results of Wireman et al. study (35).

Pike et al. have reported high frequencies of tetracycline and ampicillin resistance among isolated strains (34). McIntoch et al. showed occurrence of $\mathrm{Hg}$ and antibiotic resistance abilities in Aeromonas salmonicida. They reported resistance to ampicillin in of mercury resistant strains (15). In the present study, the highest antibiotic resistance frequencies were seen for ampicillin and tetracycline. Moreover, resistance to streptomycin and chloramphenicol was detected in many isolated bacteria from Pole Khan and Pole Petroshimi stations. Resistance to more than one antibiotic occurred in most of the $\mathrm{Hg}$ resistant isolates. These findings showed that Kor River is highly contaminated with mercury so that residing bacteria can easily gain mer genes along with the antibiotic resistance genes via conjugation or transposition. In addition, the highest frequency of antibiotic resistance was obtained for $\mathrm{Hg}$ resistant isolates from Pole Khan and Pole Petroshimi stations which were the most contaminated areas of the river.

Resistance to these antibiotics is controlled by a set of 
genes that are usually located on the mobile elements such as R100 or transposons such as Tn4 and Tn2571. Most $\mathrm{R}$ plasmids also carry Hg resistance genes. In addition, R100 encodes some enzymes that are responsible for selftranslocation and conjugation. According to these findings, isolated strains in this study may acquire antibiotic resistance genes from other bacteria which carrying $\mathrm{R}$ plasmids and transposons by conjugation or any other horizontal gene transfer method. Resistance to streptomycin and tetracycline is mediated by production of degradable enzymes and changing bacterial cell membrane permeability.

Our results clearly showed that enhancement of $\mathrm{Hg} \mathrm{lev}$ els in the environment directly increases the frequency of antibiotic resistance especially among Gram negative bacteria and family of Entrobacteriace. These bacteria are responsible for serious infections in human. Contaminated areas residents can easily get infected by such multiple antibiotic resistant bacteria. Nowadays, prevalence of multiple antibiotic resistant bacteria is one of the most important problems in the treatment of infectious diseases. Molecular analyses using antibiotic and mercury resistance gene-specific primers can reveal the presence of these genes at the same time in bacterial communities residing in mercury contaminated areas.

Using developed and effective wastewater treatment systems in Chloralkali plants and other industrial units and limiting utilization of herbicides and fungicides in agricultural fields will certainly reduce multiple resistant bacteria spread in the natural environments.

\section{Acknowledgements}

We are grateful to the staff of the environmental microbiology laboratory, Islamic Azad University of Jahrom branch for helping us in carrying out this research.

\section{Authors' Contribution}

Nima Mirzaei developed the idea and protocol, conducted the research and data analysis and wrote the manuscript. Hilda Rastegari contributed to sampling, bacterial detection and manuscript writing. Mehdi Kargar contributed to sampling, providing the protocol and data analysis.

\section{Financial Disclosure}

The article does not have any benefits for authors or any other organization.

\section{Funding/Support}

This study was financially supported by the Islamic Azad University, Jahrom branch, Fars, Iran.

\section{References}

1. Jahed Khaniki GR, Alli I, Nowroozi E, Nabizadeh R. Mercury Con- tamination in Fish and Public Health Aspects: A Review. Pak J Nutr. 2005;4(5):276-281.

2. Nascimento AM, Chartone-Souza E. Operon mer: bacterial resistance to mercury and potential for bioremediation of contaminated environments. Genet Mol Res. 2003;2(1):92-101.

3. Poiata A, Ambarus A, Badescu A, Tuchilus C. Resistance to mercury salts in Escherichia coli. Natura Montenegrina. 2010;9(3):815818.

4. Wackett LP, Dodge AG, Ellis LB. Microbial genomics and the periodic table. Appl Environ Microbiol. 2004;70(2):647-55.

5. Kiyono M, Pan-Hou H. Genetic Engineering of Bacteria for Environmental Remediation of Mercury. J Health Sci. 2006;52(3):199204.

6. Tóthová T, Pristaš P, Javorský P. Mercuric reductase gene transfer from soil to rumen bacteria. Folia Microbiologica. 2006;51(4):317319.

7. Deckwer WD, Becker FU, Ledakowicz S, Wagner-Döbler I. Microbial Removal of Ionic Mercury in a Three-Phase Fluidized Bed Reactor. Environ Sci Technol. 2004;38(6):1858-1865.

8. Barkay T, Miller SM, Summers AO. Bacterial mercury resistance from atoms to ecosystems. FEMS Microbiol Rev. 2003;27(2-3):355384

9. RayS, Gachhui R, Pahan K, Chaudhury J, Mandal A. Detoxification of mercury and organomercurials by nitrogen-fixing soil bacteria. J Biosci. 1989;14(2):173-182.

10. Skurnik D, Ruimy R, Ready D, Ruppe E, Bernede-Bauduin C, Djossou $\mathrm{F}$, et al. Is exposure to mercury a driving force for the carriage of antibiotic resistance genes? J Med Microbiol. 2010;59(Pt 7):804-7.

11. Barbosa TM, Levy SB. The impact of antibiotic use on resistance development and persistence. Drug Resist Updat. 2000;3(5):303311.

12. Mutter J. Is dental amalgam safe for humans? The opinion of the scientific committee of the European Commission. J Occup Med Toxicol. 2011;6(1):2.

13. Saha DK, Ghosh S, Chaudhuri J, Mandal A. Mercury resistance in bacterial strains isolated from hospitals and clinics. Bull Environ Contam Toxicol. 2006;77(1):88-95.

14. Aminov RI, Mackie RI. Evolution and ecology of antibiotic resis tance genes. FEMS Microbiol Lett. 2007;271(2):147-61.

15. McIntosh D, Cunningham M, Ji B, Fekete FA, Parry EM, Clark SE et al. Transferable, multiple antibiotic and mercury resistance in Atlantic Canadian isolates of Aeromonas salmonicida subsp. salmonicida is associated with carriage of an IncA/C plasmid similar to the Salmonella enterica plasmid pSN254. J Antimicrob Chemother. 2008;61(6):1221-8.

16. Huang C, Chien M, Lin K. Bacterial mercury resistance of TnMERI and its application in bioremediation. Interdisci Stud Environ Chem. 2010;3(11):21-29.

17. Manual of Oceanographic and Observations Pollutant Analysis Meth ods. 3 edKuwait: The regional organization for the protection of marine environment; 1999.

18. Wagner-Dobler I, Lunsdorf H, Lubbehusen T, von Canstein HF, L Y. Structure and species composition of mercury-reducing biofilms. Appl Environ Microbiol. 2000;66(10):4559-63.

19. Mirzaei N, Kafilzadeh F, Kargar M. Isolation and Identification of Mercury Resistant Bacteria from Kor River, Iran. J Biol Sci. 2008;8(5):935-939.

20. Harley JP, Prescott LM. Laboratory exercises in microbiology. 5 edNew York: McGraw Hill; 2002.

21. Clinical and laboratory standard institute . Performance standards for antimicrobial disck susceptibility tests.USA: NCCLS documents M100S-16;2005.

22. Ebrahimi M, Taherianfard M. Concentration of four heavy metals (cadmium, lead, mercury, and arsenic) in organs of two cyprinid fish (Cyprinus carpio and Capoeta sp.) from the Kor River (Iran). Environ Monit Assess. 2010;168(1-4):575-85.

23. Xiao-xi Z, Jian-xin T, Pei J, Hong-wei L, Zhi-min D, Xue-duan L. Isolation, characterization and extraction of mer gene of $\mathrm{Hg} 2+$ resisting strain D2. Trans NonFerrous Met Soc China. 2010;20(3):512-707.

24. Keramati P, Hoodaji M, Tahmourespour A. Multi-metal resistance 
study of bacteria highly resistant to mercury isolated from dental clinic effluent. Afr J Microbiol Res. 2011;5:831-837.

25. Jaysankar D, Ramaiah N. Occurrence of large fractions of mercury-resistant bacteria in the Bay of Bengal. Curr sci. 2006;91(3):368372p.

26. Aram M, Sharifi A, Kafeelzadeh F, Naghmachi M, Yasari E. Isolating mercury-resistant bacteria from Lake Maharloo. Int J Biol. 2012;4(3):p63.

27. Chang JS, Hong J, Ogunseitan OA, Olson BH. Interaction of mercuric ions with the bacterial growth medium and its effects on enzymic reduction of mercury. Biotechnol Prog. 1993;9(5):526-532.

28. Schneiker S, Keller M, Droge M, Lanka E, Puhler A, Selbitschka W. The genetic organization and evolution of the broad host range mercury resistance plasmid pSB102 isolated from a microbial population residing in the rhizosphere of alfalfa. Nucleic Acids Res. 2001;29(24):5169-81.

29. Pahan K, Ray S, Gachui R, Chaudhuri J, Mandal A. Ecological and biochemical studies on mercury resistance bacteria. Indian J Environ Health.1990;32(3):250-261.

30. Zhang W, Chen L, Liu D. Characterization of a marine-isolated mercury-resistant Pseudomonas putida strain SP1 and its potential application in marine mercury reduction. Appl Microbiol Bio- technol. 2012;93(3):1305-14.

31. Schluter A. The 64508 bp IncP-1 antibiotic multiresistance plasmid pB10 isolated from a waste-water treatment plant provides evidence for recombination between members of different branches of the IncP-1 group. Microbiology. 2003;149(11):31393153.

32. Petrova MA, Mindlin SZ, Gorlenko Zh M, Kaliaeva ES, Soina VS, Bogdanova ES. [Mercury-resistant bacteria from permafrost sediments and prospects for their use in comparative studies of mercury resistance determinants]. Genetika. 2002;38(11):1569-74.

33. Essa AM, Julian DJ, Kidd SP, Brown NL, Hobman JL. Mercury resistance determinants related to Tn21, Tn1696, and Tn5053 in enterobacteria from the preantibiotic era. Antimicrob Agents Chemother. 2003;47(3):1115-9.

34. Pike R. Prevalence and antibiotic resistance profile of mercuryresistant oral bacteria from children with and without mercury amalgam fillings.J Antimicrob Chemother. 2002;49(5):777-783.

35. Wireman J, Liebert CA, Smith T, Summers AO. Association of mercury resistance with antibiotic resistance in the Gramnegative fecal bacteria of primates. Appl Environ Microbiol. 1997;63(11):4494-503. 